\title{
DIVINE PROVIDENCE AND CHANCE IN THE WORLD: REPLIES
}

\section{INTRODUCTION}

First and foremost, I would like to express my deep gratitude to all the authors who agreed to contribute to the present issue of Roczniki Filozoficzne and prepare their papers addressing the ideas and problems discussed in my two publications (Łukasiewicz 2014, 2020). I am grateful for their critical remarks, comments and formulation of alternative proposals regarding God's action in the world and the role of chance and randomness.

Before I refer to the comments made, I want to explain the relationship between the two works under discussion: the book Opatrzność Boża, wolność, przypadek. Studium z analitycznej filozofii religii (Providence, Freedom and Chance: A Study in the Analytic Philosophy of Religion) (2014) and the paper "Divine Providence and Chance in the World" included in the present issue; some polemics refer to the paper and others to the book. In both these works I address the problem of God's action in the world. However, in the paper this is the main issue, while in the book it is a problem discussed in a broader context provided by the major varieties of contemporary theism, such as classical theism, Molinism and open theism, which are reconstructed there. In my consideration of these varieties, I concentrate on the claim of the opponents of classical theism that the God of classical theism does evil, which amounts to theological Calvinism. The rationale for this allegation is the following: if we assume God's attributes such as simplicity, omnipotence and omniscience understood in a classical way (i.e., as in Augustine, Anselm and Thomas Aquinas) and we assume that God created the world, the conclusion that God does evil necessarily follows.

Dariusz LuKaSiewicz, Prof. Dr Hab., Head of the Chair of Logic and Ontology, Institute of Philosophy, Kazimierz Wielki University; address for correspondence: ul. Ogińskiego 16, 85-092 Bydgoszcz, Poland; email: dlukas@ukw.edu.pl; https://orcid.org/0000-0003-1786-0149. 
The allegation of theological Calvinism against classical theism is formulated by open theists, process theists and Molinists. The proponents of classical theism are said to adopt the compatibilist concept of free will (i.e., freedom of will is compatible with God's action determining human decisions and actions). Open theists, Molinists and process theists defend the libertarian doctrine of free will claiming that human is the source of his/her own acts of will, and there are different possibilities from which he/she can choose or refrain from choosing (the principle of alternative possibilities). The theists who defend libertarianism emphasize that God, by creating a world in which rational and free beings exist, wanted those beings to freely enter into a relationship with Him. The freedom of will, undetermined by God's action, also entails the existence of evil, which is the result of some free choices. Libertarian freedom and God's intention to establish a relationship with humans are great goods testifying to the divine goodness.

Among the proponents of the libertarian concept of free will (Molinists and open theists), there is a dispute concerning the existence of God's detailed plan for the world and every individual being in it. Molinists defend the conception of God's foreknowledge of the world in the form of "middle knowledge," whereas open theists postulate that God does not know the future and does not have a single detailed plan. In the context of this dispute about the nature of God's knowledge and the existence of God's plan, I advocate for a conception encompassing the libertarian freedom of will and relative autonomy of the created world. Defenders of the relative autonomy of the world (it is relative because God is the creator of the world, sustains it in existence and can act in it) postulate that in such an autonomous world there occur random events undetermined by God's action. Importantly, the occurrence of random events $\left(\mathrm{C}_{1}, \mathrm{C}_{2}, \mathrm{C}_{3}, \mathrm{C}_{4}\right)^{1}$ is not an argument for atheism. Following the defenders of randomness, or "purposeful randomness" as William Hasker puts it (this issue), I try to show that the existence of chance could have been part of God's creative will, and therefore, chance is not an antithesis of providence. The idea that chance is part of God's plan is called "probabilistic theism" (Eukasiewicz 2014). The aim of my paper "Divine Providence and Chance in the World" (this issue) is to demonstrate how randomness can be compatible with God's existence; thus, it continues the main idea of the book, but the paper is also focused on possible models of God's action in the world, including the actions that cause miracles.

\footnotetext{
${ }^{1}$ Events are random if $\mathrm{C}_{1}$ they are without cause (i.e., ontological chance); $\mathrm{C}_{2}$ they are not planned/ designed; $C_{3}$ they are unpredictable; $C_{4}$ they are pointless; $C_{5}$ their probability is extremely small; or $\mathrm{C}_{6}$ they result from the coincidence of different causal chains (Lukasiewicz 2014).
} 
In what follows, I will reply to the papers included in the present issue whose authors have offered their critical comments related either to my book (Lukasiewicz 2014) or to my paper (this issue). I will proceed in the following order. First, I will refer to the articles addressing, among others, the issue of providence and God's action in the world, namely the papers by William Hasker, Thomas P. Flint, Jean-Baptiste Guillon, Peter Forrest and Jeffrey Koperski. Next, I will respond to the text about the nature of the human will by Stanisław Judycki. Then, I will proceed to the papers concerning the nature of God and His attributes, such as omnipotence (Ryszard Kleszcz), perfect goodness (Ireneusz Ziemiński) and simplicity (Ryszard Mordarski). Finally, I will refer to the three papers addressing or touching upon the concept of chance, authored by Marian Grabowski, Błażej Gębura, and Jacek Wojtysiak.

\section{REPLY TO WILLIAM HASKER}

Professor William Hasker, in his "How to Make a World" (this issue), presents a vision of the world that allows for the occurrence of randomness and chance. In his view, it is not only possible but also very likely that the world was created evolutionarily and it has value for God, the Creator, as evidenced by the size of the universe and the diversity of creatures in the nature we know. He admits that it is not impossible that God has planned everything and guides the process of evolution; however, taking into account what we know about the world, this idea does not seem plausible.

The above view is fully in line with the position I defend, but Professor Hasker disagrees with my theses regarding some of God's attributes, such as omniscience, timelessness, omnipotence, or God's immutability. He writes that the conception I defend, by accepting libertarian freedom of the human will, purposeful randomness, God's timelessness and unlimited omniscience, is incoherent. His argument has it that if God foreknows infallibly what will happen, no matter whether $\mathrm{He}$ is timeless or exists in time, the libertarian freedom of will is impossible. Future events about which God foreknows (or foreknew) that they will (would) happen must happen, so they are necessary; they cannot be different from what God knows of them. If God is in time, then the necessity of the past works, and if God is beyond time, the necessity of eternity works. Hence, open theism, of which William Hasker is an outstanding defender, rejects God's foreknowledge of the future. But one could raise the following question: Why does God's infallible knowledge make future events necessary? If God exists beyond time in such a way that the past, present and future are given to Him simultaneously, as claimed by Anselm, 
He has an accurate knowledge of every event (Rogers 2008). If God gave rational beings the capability of self-determination, we acknowledge that they can decide about their present and future, and their past is the result, at least to a certain extent, of their past action. Why is human self-determination irreconcilable with God's knowledge of how it is done? Why should we assume that God's foreknowledge of how free persons (will) behave prevents their freedom? William Hasker argues that the infallibility of prior knowledge and the modality of time necessitate future events covered by this knowledge. However, is the fact that God knows infallibly that person $\mathrm{S}$ will freely choose $\mathrm{A}$ not a guarantee that person $\mathrm{S}$ will indeed choose $\mathrm{A}$ in a free manner? If $\mathrm{S}$ freely chooses a non-A, God would eternally know that $S$ would choose a non-A (Craig 1987). The second point is the following: What is the nature of necessity that $\mathrm{S}$ will choose A, assuming God's prior and infallible knowledge? Is it a metaphysical (temporal), logical or epistemic necessity? As for the epistemic necessity (God knows infallibly that p; it is necessary that p: p: S chooses A), divine knowledge does not make the event necessary in the sense that $S$ could not do otherwise than he did. God knows infallibly that $\mathrm{p}$, because $\mathrm{S}$ causes p. God can cause $\mathrm{S}$ to choose A if He wants to, but if He wants $\mathrm{S}$ to retain the ability to self-determine, then S will have the possibility to choose A by himself/ herself, and this possibility is guaranteed by the infallible divine foreknowledge that $\mathrm{S}$ will freely choose A.

Open theism holds the view that the nature of time created by God generates the necessity of the past if God exists in time, which necessity cannot be overcome even by God Himself, or the necessity of the eternity if God is beyond time. God has no control over time or eternity; He can only choose whether He wants to exist in time or in the eternity, but God has no effect on the nature of time and eternity. These natures are independent of God in the sense that by creating time, God could not create a different time than the one in which He Himself is subject to the necessity of the past. It seems to me that this view may be questioned: it may be the case that God's omnipotence can have control over the nature of time. Connected therewith is another problem: Did God know beforehand that $\mathrm{He}$ would create the world before He created it, or was His knowledge about creation timeless? If He knew before, He had to exist in time before the creation of the world took place, time would be independent of the world, and creation would be necessary. And if He knew it timelessly and infallibly, then His knowledge would also make creation necessary. Thus, the necessity of time and eternity applies to all beings, including God, or it does not concern God. If that necessity does not concern God, it does not apply to His infallible knowledge either. But if it is applicable, God does not act freely. 
I would add that if God could not really, as the open theism claims, cause time to have a different nature than it does, I would prefer open theism to the concept of God's prior knowledge depriving man of libertarian freedom of will. However, it is difficult to understand the reason why God cannot be viewed as the Lord of time. Moreover, the theism which I defend is a Christian theism based on the Bible and tradition. Biblical testimonies are not conclusive, but according to many authors, they speak up for God's eternal knowledge rather than for God's being in time.

Hasker raises another difficulty concerned with God's timelessness; if God is timeless, His prior knowledge is providentially useless. God knows too late what will happen and, therefore, He cannot react effectively. But is the God of open theism in a clearly better position? God, according to open theism, never knows in advance how free persons will act, and they can act against God's intentions. So until a person makes a choice, God does not know infallibly what he/she will do, and He cannot react soon enough. God can react only after a person has freely decided to do something. Thus, He must wait until He knows what happens. Hitler unleashed WW2 although, at the time when it began, God may not have known how terrible it would be, and therefore He waited with a reaction. But it is God's waiting that makes His reactions too late, at least in some cases. Open theism can resort to the omnipotence of God and conclude that, whatever happens, God will find the right response in the future. However, this policy of waiting, forced by the nature of time and human freedom, makes many evil events possible, including pointless evil. Professor Hasker has developed the theodicy of non-intervention, in which he explains why God does not prevent evil, pointless evil included (Hasker 2008). Accordingly, it is not that God is simply waiting; God has adopted a nonintervention policy for which $\mathrm{He}$ had some important reasons. But in my view, the God of open theism, who does not have prior knowledge, is not very active and reactive in the world. He reacts to events in the world only in the sense that $\mathrm{He}$ changes with the increase of His knowledge of what is happening, reacts to what has happened with sadness or joy, but He does not work in a causal way. In that respect, the God of open theism is similar to the God of process theism. In a theism that recognizes God's timelessness, it can be assumed that God who knows all events in advance can take action to respond to these events. His eternal knowledge is not only about what will happen in the world, but also about His reaction to these events.

However, I wish to emphasize that, apart from the above-mentioned differences concerning the nature of God, open theism is a view which is close to probabilistic theism as far as it acknowledges the existence of purposeful randomness in the 
world, insists on the libertarian freedom of human will capable of self-determination, and, unlike other theistic views, it allows for the possibility of pointless evil.

\section{REPLY TO THOMAS P. FLINT}

Professor Thomas P. Flint, in his polemical paper "Providence, Chance, Divine Causation, and Molinism: A Reply to Łukasiewicz" (this issue), outlines the Molinist view on chance and formulates a number of critical remarks to my paper included in this issue. Professor Flint underlines that every detail of the world is important, and the order of the whole depends on the larger and the smallest parts; among others, he refers to the well-known "butterfly effect."

However, this is not the only possible view on the systemic nature of the world. In the general systems theory (GST), Ludwig von Bertalanffy $(1968,1975)$ and Ervin Laszlo (1972a, 1972b) pointed out that the real systems existing in the world, whether physical, biological, social or cognitive, have a considerable degree of flexibility; elements of a system can be freely exchanged and this does not threaten the identity of a system. It is not the case that every element counts; to use Laszlo's comparison, it is like in business corporations where everybody from the president to the office boy can be replaced and the company can preserve its characteristics. So it does not matter which of the individual workers does a particular job as long as there is someone to do it. According to GST, what makes a particular entity a system is a certain hierarchic order revealed in structure and in functioning. Another vital property of a system is the capacity to maintain its structure around a certain steady state despite perturbations coming from the environment and to reorganize its structure should environmental challenges require that. But there is no reason to postulate a close mutual dependence between the system's elements; in real systems, the identity of a particular element is not important and individual elements do not determine the system's identity as a whole (E. Łukasiewicz 2006, 108).

It happens that elements of certain biological systems, formed by evolution and inherited by successive generations within the species, are pointless and completely dysfunctional; our appendixes or wisdom teeth make a good example. These elements do not contribute to the functionality of the body system, and they do not give evidence of the existence of any precise design or plan. Natural systems abound with such redundant, ill-fitting and insignificant elements. Many biological organisms are not economically and purposefully designed (take the example of the giant panda); they are not like man-made products where every element is for something. Our language is one more example of an open, well- 
functioning system with innumerable redundant elements. In any language, the phonemic and lexical resources, morphosyntactic structures and prosodic features, which are capable of encoding information, far exceed the communication needs of the speakers - a significant part of information that is encoded in language is simply redundant and forms what is called "noise" (E. Lukasiewicz 2008). Redundancy in the world is pervasive, but, paradoxically, this is a good solution because redundancy enhances the system's adaptability and makes it less vulnerable in case of environmental disturbances. Thus, some of these redundant and insignificant elements may eventually prove useful, but, note, most of them come and go without any role to play.

The idea of open self-organizing systems with the ability to adapt and survive in a dynamically changing environment is extremely important for the vision of the world proposed in my paper (this issue) and also in my book (2014). The existence of redundancy, randomness and individual dysfunctions at lower levels, and self-organization with order at higher systemic levels - as suggested by many system theorists - is essential for a plausible concept of the universe. What is fundamentally different in this approach to natural systems and the world, as compared to Professor Flint's views, is the role of a particular element or event in the created world. If the natural systems and the world were perfectly designed down to the smallest detail, as Flint argues, the world would be extremely poor in content and lacking in creative ability. ${ }^{2}$ In the context of the history of salvation, a good formula describing God's action is that God fixes whatever He wants to be fixed and leaves the rest open. I do not consider it necessary that all events and states of affairs in the world need play a role in the history of salvation.

The second issue I would like to stress here is the degree of independence of the world from God's will. I am inclined to attribute a greater degree of independence to the created world than it is claimed in the Molinist approach. Although Molinism presupposes and defends the libertarian freedom of will, divine providence is very active in the world. God places free persons in well-defined situations knowing - on the basis of middle knowledge - how they will behave and what choices they will freely make. Although He does not create counterfactuals of freedom and does not make them true, he chooses certain persons for certain situations, having complete and strict control over the world as a whole and every part of it; and $\mathrm{He}$ has a good reason for selecting a particular relationship between people and situations. This way of creating a world leads to a very difficult question about the existence of evil. The answer to the problem of evil which Molinists provide

\footnotetext{
${ }^{2}$ The matter does not concern the so-called mathematical chaos but simply a random, pointless and unplanned course of events of any type; see Michał Heller's book Filozofia przypadku $(2011,181)$
} 
is the Free-Will Defense formulated by Alvin Plantinga. However, the problem of evil remains with us because it is the active divine providence that places people in situations where terrible evil is to be committed. Does God acting in this way merely permit evil, or does He want it to happen? My intuition of God's goodness is better satisfied by the "passive" providence for which I advocate than by the active providence of Molinism.

Regarding the interpretation of Alvin Plantinga's views, Thomas P. Flint is right when it comes to Plantinga that God's actions at the quantum level do not pose a threat to the freedom of the human agents' will because Plantinga defends dualism and claims that God leaves room for actions of other agents at the quantum level (2011, 119-20). I write about Plantinga's dualism and possible action of the soul at the quantum level, assuming GRW, in my 2014 book. The problem of determinism which I mention would arise for Christian materialists. Nevertheless, the concept of God's continuous action at the quantum level is not free of difficulty. One of them is the problem of pain and suffering in nature-and the problem of the inadequate frequency of miracles connected therewith. Even if the counterfactuals of chance are independent of God's will, they have been selected by God's free will when making the decision about creating this world.

As for the ambiguities regarding the concept of chance, I will return to this issue and try to clarify some of them in the replies below (see my reply to Jacek Wojtysiak).

Finally, the problem to be mentioned is God's omnipotence. Assuming that the logic and mathematics that we know and use have been established by God, and assuming it is a logic of non-contradiction, I consider Flint's concerns to be too far-fetched. But I will not dwell on this problem now as it will be elaborated in my reply to Ryszard Kleszcz.

I admit that in my conception of providence there are certainly many things that need to be clarified and disambiguated; some must be rectified. However, if true counterfactuals of freedom and middle knowledge do not exist, as William Hasker $(1989,2000)$ and many others argue, and secondly, if we do not accept theological determinism, but we accept the possibility of causeless chance events taking place in the self-developing world, there remain two options: open theism or God's timeless ("passive") providence. I am inclined to adopt the latter. Which of these options is closer to the tradition is a question that I leave to the readers' assessment. 


\section{REPLY TO JEAN-BAPTISTE GUILLON}

In "Divine Providence: Fine-Grained, Coarse-Grained, or Something in Between" (this issue), Professor Jean-Baptiste Guillon formulates a number of comments and questions concerning my text on divine providence and chance (this issue), but he also proposes his own model of providence. It is an intermediate model, which might be situated between the models of an extremely detailed providence and a general one. In Guillon's paper, the main intention of my text is aptly reconstructed, which is, indeed, an attempt to weaken the argument from evil, in its evidential form in particular. Each of the valuable comments offered in his paper would require a separate discussion; unfortunately, this is beyond the scope of the present text. I agree with Guillon that the providence model that he calls "fine-grained," with God's control over every detail, is difficult to maintain-for various reasons. I also accept his thesis that God is interested in the well-being of every creature. The difference of opinions between Guillon and myself concerns the question of how God is interested in the good of every being, that is, how the divine providence works.

Guillon writes that my God is rather concerned about some global good of this world and the future one (New Earth, new heaven), but not about the good of every individual creature. In his model of providence, God acts in the world causally at different levels, including the quantum level, in a way that favors thus individualized good. His providence is a manifestation of love for individual creatures, and is sensitive to their pain and suffering. In my opinion, the almighty God-Creator of the world could act in this way, but I suppose it is not the way He acts. Without entering into a detailed discussion on how the well-being of creatures could be understood, it is plausible for Christians to assume that salvation is the greatest good. It is assumed by Guillon (and many other theists) that God is causally active in various misfortunes and tragedies affecting us in our earthly life; furthermore, the reason for divine activity is the good of created and loved beings - given the assumption that sins and sufferings are to liberate humans from selfishness and lead them to salvation and happiness. This scenario might occasionally be true, but most tragedies and sufferings that we know about seem very unlikely to contribute in any way to salvation, well-being and happiness; so it is difficult to understand how perfectly good and almighty God might actively participate in their taking place. Hence, Guillon's model of providence FAPP (abbreviated from: "for all practical purposes"), although firmly rooted in the Christian tradition, is difficult to accept, especially in the context of our knowledge of the scale and intensity of suffering occurring throughout history. 
In my conception of providence, which Guillon calls a "coarse-grained" model, God does not participate causally in bringing about human and not only human suffering (no matter whether it might be conducive to salvation or not so). Though God permits tragedies to happen, He rather acts as God of hope, offering comfort in suffering. A model of providence in which God is directly (causally) active in afflicting us with misfortunes (for our good), and then offers comfort, is hard to accept. In my model, the created world itself generates various, good and bad situations, which may bring happiness or misery.

Guillon writes: "Is 'natural' chance a good in itself? For whom? For protons? Just for the aesthetic property of having a contrast class with determinism?" This question is raised in the context of Peter van Inwagen's theodicy, where randomness and chance are conceived of as an instrument of reconciliation between humanity and God after the Fall. In my view, natural chance is rather an instrument for relatively autonomous development of the world and has nothing to do with the Fall. Perhaps God finds a world with the ability to self-develop more valuable than a world strictly determined by His creative will? Of course, a deterministic world may also develop, as the nineteenth-century deists claimed. However, the number of possibilities for the world's development is certainly greater in indeterminism (with the premise of the existence of chance) than in determinism. This approach does not seem contrary to the Bible; let us remember that, after the creation of the world, God recognized that the world is good, not bad and corrupt (cf. the Book of Genesis, but note that in Peter van Inwagen's account, the world became hostile and extremely unpleasant to humans as a result of the original sin). It is hard to believe that the power and impact of God's action creating good things could eventually amount to less than the negative effects of the Fall. Therefore, if we reject van Inwagen's theodicy, chance cannot be accounted for as an instrument of reconciliation between humanity and God. Nor is it accurate to say that chance is something good in itself and for itself. As stated in my foregoing reply to Thomas P. Flint, chance, combined with variation and redundancy, is a must in any open, self-organizing and self-maintaining system striving to survive in its environment - and the world we live in constitutes such a system.

Another problem, as argued by Guillon, is that, in the model of providence I suggested (and also in the providence model of open theism), there is a metaphysical threat that all human beings will freely reject God. But let me note that it is also possible - and even more likely - that all human beings will freely accept God. There is no reason for a Christian theist to believe that there is a real threat that everyone chooses condemnation. Why believe that such a scenario is more likely than the possibility that at least some will choose salvation? Here, I set aside the 
problem that, as said in the Bible, salvation depends not only on what humans will choose, but primarily on what God does.

Guillon notes that open probabilistic theism-when it comes to miracles-is not different in substance from the traditional view which I call traditional interventionism. The difference is described as only verbal, and I admit that this remark is essentially correct. It is possible that the omnipotent God, by establishing the laws of nature, has decided that He will break some of them or suspend their validity in certain situations.

The adherents of traditional Christianity who assume the existence of miracles but want to stay sensitive to the claims of modern science tend to avoid terms like "violation of laws of nature." In discussions with the opponents of miracles, they will say that God does not violate the laws of nature but acts either according to them or "beyond" them. Those who claim that God always acts according to the laws of nature are not likely supporters of traditional interventionism, but those who claim that God acts or can act beyond these laws when causing miraculous events hold views that might be subsumed under traditional interventionism.

Finally, I would like to mention that I find Jean-Baptiste Guillon's comments on the fine-tuning argument very convincing and inspiring, but because of the limitations on the scope of this text, I must leave the discussion of this topic for another occasion.

\section{REPLY TO PETER FORREST}

Professor Peter Forrest (this issue) has formulated an interesting but controversial theodicy. He criticizes anatheism, which is a view that statements about God should be understood by analogy, not literally, and he defends the position he calls "theism," according to which the biblical claims about God must be understood literally. What is important for his conception is that God be conceived of as an agent - in the same sense as a human agent. Consequently, God as a loving person is loving in the same way as a human agent can be loving. The God of theism (in the aforesaid sense) permits of terrible evil out of love for humans, because through this evil, God can bring about a true union with human beings. This theodicy may raise certain doubts; in my opinion, no human who truly loves other people would allow terrible evil to afflict the people loved. If that is the case, I would say that such love to others should be understood differently, perhaps metaphorically, but not literally.

Another problem with Peter Forrest's theism concerns God's attribute of simplicity and, thus, the transcendence of God. The doctrine of God's simplicity explains 
the transcendence of God as follows: God is the only being absolutely simple, and therefore, He is "quite different." In my opinion, this view must be rejected by Forrest as a consequence of his rebuttal of anatheism and his adopting of the view that predicates referring to God refer to creatures as well. As he argues, when speaking of God's attributes such as omnipotence, omniscience, goodness, love, or personality, we must clearly understand their meaning. Thus, there must be some semantic basis for this attribution, a certain convergence of meanings in the words when they refer to God and to created beings. Therefore, it is allowed to say that since God is good, Socrates is good too. But then it is clear that the doctrine of simplicity becomes inconsistent, which may be proved as follows. (1) Necessarily, for each $x$, if $x$ is maximally perfect in terms of $F$, then $x$ is $F$. It follows from (1), given that God is perfectly good, that (2) God is good. For if God is perfectly good, He is good. But among creatures, there are also beings of a certain degree of goodness, hence it is allowed to consider the truth that (3) Socrates is good. Accordingly, from (2) and (3), it is apparent that (4) there are properties owned by both God-Creator and created beings. But if $x$ and $y$ have $P$, then $P$ is not identical to either $x$ or $y$. And that is why God's properties are not identical with God. Thus, the doctrine of God's simplicity is false (Vallicella 2010, 6). Therefore, it can be claimed that Peter Forrest's theism is irreconcilable with the attribute of God's simplicity; however, this attribute, though thorny and challenging, is important for both traditional and contemporary theism.

Peter Forrest argues that the ontological chance $\left(\mathrm{C}_{1}\right)$ is irreconcilable with the libertarian freedom of will. In my opinion, it can be reconciled. I am not saying that for any human decision or action there is no explanation in the form of reasons or motives. I only claim that there may be decisions and actions for which it is impossible to indicate a reason or motive, or that one can act against reasons and motives. These actions are irrational, but they do not cease to be free in the libertarian sense. Also, we have the ability to reflect on our irrational past actions; even when we do not understand why we did so-and-so, we may wonder whether we have done the right thing and how we should have behaved. Free and self-aware agents do not need to be always determined by reasons and motives in anything they do; nor do they need to always know their reasons and motives. A sporadic occurrence of ontological chance does not entail that human rational and responsible agency is undermined. 


\section{REPLY TO JEFFREY KOPERSKI}

Professor Jeffrey Koperski, in his article "Divine Action and the Laws of Nature" (this issue), made a number of valuable comments to my paper (this issue), which I treat as supporting the position of probabilistic theism. His remarks on the cosmological constants and the essence of the laws of nature appear to me thoroughly accurate, and their acceptance does not require me to fundamentally change or abandon the views I advocate. Koperski defends the thesis about God's ability to act in the world, including extraordinary action or miracles; his position allows for recognizing the vital role of modern science for theism, but, importantly, it does not imply the need to demythologize Christianity (pace Ziemiński, this issue).

Regarding cosmological constants, my suggestion in the paper is that these constants could have resulted from spontaneous self-tuning, so they are-in a senseaccidental. Koperski holds that cosmological constants have been designed by God. I believe that if we recognize that design as God's activity in the world, it will not undermine the basic thesis that the world is relatively autonomous and has the capacity of "self-creation." If the world is viewed as having the ability to self-organize and develop, it must have been created in a certain way, and the cosmological constants with their values may be considered as God-designed.

Jeffrey Koperski also notes that, regardless of whether the laws of nature are deterministic or indeterministic, in most cases, they allow external factors to act, so they are also open to God's actions. However, it seems that if the laws of nature were deterministic, and God could act at all levels of the world without breaking those laws, then the world's ability to self-organize and self-determine would be much lesser than in the world with indeterministic laws. Moreover, the libertarian freedom of will is not possible in a deterministic world. If we assume determinism, there is only one possibility of what the world will be like. In that situation, even if an individual person has the ability to choose different options, there is actually only one option that can be chosen. It may be that Jeffrey Koperski is referring to the determinism of the laws of nature which does not exclude the existence of various options for free and intelligent agents. If that is the case, freedom of will in the libertarian sense would be preserved, and whether the world is or is not deterministic would be irrelevant to the possibility of libertarian agency. However, this would require a revision of the concept of determinism. 


\section{REPLY TO STANISŁAW JUDYCKI}

In "God's Insurmountable Will and the Mystery of the Freedom of Created Beings," Professor Stanisław Judycki (this issue) presents an interesting and important concept of will. He points to two interpretations of the notion of human will. First, will may be understood as a machine or a sort of device generating acts of will that humans are equipped with (this interpretation is rejected by Judycki). Second, the human will may be regarded as an expression of an individual essence possessed by each of us and created by God; according to this view, each act of will is consistent with the individual essence of an agent. The second view is undoubtedly a form of compatibilism. I find both these views difficult to accept. Like Stanisław Judycki, I believe that will is not completely independent of other human faculties. However, it is difficult to agree with the second view of will, because the individual essence of each person is created by God and, as one may suppose, it is determined in the act of creation. It is not that God determines directly every human action and choice, but God gives each of us a specific nature, and this nature makes us act as we do, and not otherwise, in situations that are not contingent either. The situations in which we act are not contingent because God has eternally established what they will be like for each individual. Every suffering and every joy are part of a detailed plan (providence) for each individual person. The difference between Judycki's view and my position is that I claim that neither the individual acts of will nor human individual nature nor the circumstances in which the will works are strictly determined by God. Rational and free persons determine their natures by their own decisions and actions. It is the freedom to self-create and shape our moral character that God has equipped us with.

Professor Judycki raises an important issue that my book (2014) is lacking in existential considerations; while discussing the nature of God and the world, it does not deal with the destiny of individual people. I consider this critique justified to some extent. However, I would say that the world in which people can act freely, in situations unplanned (or at least mostly unplanned) and undetermined by God, is not an expression of God's indifference to human beings. It is plausible that God constantly acts on the mind and conscience of each individual by subtly suggesting the best options to choose in a given situation. However, this is not an action that might causally determine how free people will act.

In Judycki's paper I consider it extremely important that he mentions the possibility that all persons, except those who persistently wish evil, will be saved. This scenario of universal salvation is important because it can weaken possible allegations that God does evil, which might be raised against Judycki's views. If 
almost every person is in God's detailed plan destined for salvation, and God has the power to provide this good, the threat of theological Calvinism is significantly reduced.

\section{REPLY TO IRENEUSZ ZIEMIŃSKI}

In his paper "Is God (Perfectly) Good?" (this issue), Professor Ireneusz Ziemiński formulates several important critical comments concerning my book (Łukasiewicz 2014). The first is that natural, or philosophical, theology has no existential meaning. Philosophers may devise certain solutions, for example, to the problem of the compatibility of human freedom and God's omniscience, but those solutions will be irrelevant to people who need prayer. What matters, in his opinion, is that the subjective idea of God to whom a person prays gives that person a feeling that the God to whom the prayer is addressed will not remain indifferent. By and large, I consider this skepticism about the role of philosophical theology justified; nevertheless, I believe that, in certain situations, philosophical theology can have practical significance. For example, in the case of the apparent conflict between science and religion, if we can demonstrate that there is no "deep" conflict between science and religion, this can be important for religious people who respect science. Also, philosophical theology can be useful for those believers who feel inclined to form a rational religious worldview.

Another issue raised by Ziemiński concerns demythologization of the Bible and Christian religion. He argues that anyone who, on theological reflection, refers to science must come to the conclusion that the only rational step is demythologizing of the Bible, because the biblical content (e.g., descriptions of miracles) cannot be reconciled with the modern science and must be considered a myth. In response to this claim, I will say that biblical miracles need not be regarded as contrary to science. We cannot know whether and which miracles from the Bible really happened, and which are products of the authors' visionary imagination; however, I believe that miracles, if they happen, need not be contrary to science. In (2014) and also in my paper in this issue, I try to show-following Alvin Plantinga's argumentation (2011) - that miracles are reconcilable with modern science. Jeffrey Koperski's article in this issue offers a very good development of this position.

In "Is God (perfectly) good?" perhaps the most challenging claim concerns the thesis of God's perfect goodness. The thesis is accepted by me (2014) and other theists but, as Ziemiński argues, it is done without sufficient justification. The only basis I refer to, as Ziemiński notes, are Anselmian intuitions. He argues that the fact of the occurrence of terrible evils contradicts God's perfect goodness. In 
response to this allegation, one could say that there are two possibilities: there exists the best possible world and the world we live in is the best possible, or the best possible world does not exist. If our world is the best possible, then God, by creating it, did not act in a way incompatible with the idea of perfect goodness. What alternatives did He have? To create nothing or create a world worse than the best possible. Regarding the latter option, we do not know, however, whether God created a world worse than the best possible. If there are no best possible worlds, every world whether God creates is worse than the one He could have created. Regardless of which world is created, it will always be possible to raise the objection that a better world could have been created. In my opinion, this is not a sufficient basis to reject the thesis of God's perfect goodness. The position I defend is that the created world has the ability to self-determine, and it is not only God who bears responsibility for what the world is like. If the freedom and autonomy of creatures are real, God is not the perpetrator of evil, although $\mathrm{He}$ undoubtedly allows it to happen, and in that sense He is responsible for the existence of evil. Christian theism proclaims that God participates in the sufferings of creatures and is not indifferent to the evils of this world. I agree with Ireneusz Ziemiński that it is impossible to infer God's perfect goodness out of other attributes such as omnipotence, omniscience, or simplicity. Perfect goodness is a separate aspect of the being beyond greater than which cannot be conceived. I believe that it is possible to demonstrate, by ontological arguments, that God is perfect, but the thesis of God's perfect goodness is difficult to defend if the possibility of ontological proof is rejected, as in Ziemiński (2010).

\section{REPLY TO RYSZARD KLESZCZ}

In the paper "The Chance and the Divine Providence. Methodological Notes with Pascal in the Background" (this issue), Professor Ryszard Kleszcz, when referring to my book (2014), pays special attention to the concept of God's omnipotence in probabilistic theism and the problem of miracles. He believes that philosophically competent understanding of omnipotence should respect the principles of logic, including the principle of non-contradiction. He refers to Richard Swinburne's conception of divine omnipotence (Swinburne 1993), which he interestingly modifies. As he stresses, a particularly dangerous consequence of the adoption of God's unlimited omnipotence is the possibility that God might change the laws of nature or moral principles. That possibility and various paradoxes of omnipotence mentioned in the paper should incline us to opt for the concept of limited omnipotence. My view on the omnipotence presented in the book (2014) is 
basically in line with Kleszcz's stance, and it is also congruent with the majority view on omnipotence expressed within modern theism. In my paper (this issue), I suggest a stronger version of omnipotence, but it is worth noting that the concept of strong, or absolute, omnipotence is nothing unusual and unheard-of. There are thinkers (Stanisław Judycki, Michał Heller, Hugh McCaan) ready to embrace the concept of such unlimited divine omnipotence. Heller, who is a dedicated adherent of scientific methodology and defends the thesis of "purposeful randomness" in the world, suggests that our imposing of the rules of human logic on God is a form of anthropomorphism (Heller 2014). Moreover, the rejection of the principle of noncontradiction in the context of God's omnipotence does not entail a philosophical rejection of all logic in philosophical discussion; in modern logic, there are different varieties of paraconsistent logic. Judycki, in turn, believes that God's actions such as incarnation and resurrection are actions beyond classical logic. My position is that God can act, if He wants to, contrary to the logic we know. However, we do not know whether God actually acts in this way. Besides, if the principles of logic and morality depend on God's will, it does not imply that God will actually change them. Furthermore, if logic, mathematics, the laws of nature and morality depend on God-Creator, His will is a guarantee of their validity.

When it comes to miracles, Professor Kleszcz notes that, according to the probabilistic theism, the world created by God has the ability to develop and selfcreate, which must imply that God cannot perform any extraordinary action in the universe. I cannot agree with that conclusion; in my view, though the world has the ability to self-organize and self-determine, it does not imply that God cannot cause any event in it. Innumerable events and processes are the results of secondary causes; moreover, it is possible that many have no causes at all, but this does not mean that all events are like that. Probabilistic theism and miracles are compatible with each other.

\section{REPLY TO RYSZARD MORDARSKI}

In "Probabilistic Theism and the Traditional Doctrine of Actus Purus" (this issue), Professor Ryszard Mordarski argues that the way God's simplicity is captured in my book (Lukasiewicz 2014) and my attempt to defend the attribute of simplicity against the allegation of inconsistency are inadequate and irrelevant to classical theism, especially to Thomas Aquinas' position. Also, he argues that the varieties of probabilistic theism considered in my book lead to serious difficulties. In the Anselmian theism, which assumes God's timelessness and might be seen as a variety of probabilistic theism, it is difficult to defend the possibility of truly 
random events in the world. On the other hand, if the probabilistic model with limited omniscience is adopted, like in open theism, one must admit that God's control over the world is limited and there emerges the problem of risk that God takes by creating the world whose future is not infallibly and in advance known to Him. Furthermore, Mordarski notes that it is a mistake to adapt our concept of God to modern scientific theories, because science is changing, and our metaphysical conceptions tailored to present-day ideas in science may prove wanting in the future. In particular, if scientific theories opt for determinism one day, the probabilistic models will lose their value. Therefore, it is necessary to develop metaphysics independently, or regardless of science.

When it comes to Mordarski's objection to discussing God's simplicity in terms of modern metaphysics (a model in which God is the subject having attributes and is identical to His attributes), we need to consider the question whether we are able to think and talk about simplicity in terms of Aquinas' medieval metaphysics, as advocated by Mordarski. Can we really abandon the concepts of property and state of affairs, and instead, speak of God as a pure act of existence? This seems to be a difficult task, although I am not saying that it cannot be done. But if such a project were successfully implemented, this would not affect my position because I am defending simplicity.

As for the difficulties of probabilistic theism in the Anselmian version, they consist in the apparent conflict between the concepts of chance $\left(\mathrm{C}_{1}, \mathrm{C}_{2}, \mathrm{C}_{3}, \mathrm{C}_{4}\right)$ and the divine omniscience. I suppose that Mordarski means, assuming God's simplicity, that God's omniscience is identical to His will and His power, so anything that God knows He also wants and causes; hence, chance events $\left(\mathrm{C}_{1}\right.$, $\mathrm{C}_{2}, \mathrm{C}_{3}, \mathrm{C}_{4}$ ) are impossible. This problem can be addressed as in the case of Jacek Wojtysiak's allegation (see below and Wojtysiak's paper in this issue): God wants $\mathrm{C}_{1}$ as a certain type of chance, but does not cause A to happen (token of type), only allows that A can happen. He knows that A will happen, but He knows A's occurrence as not caused by Him directly, and He acts so as not to cause A to happen. The concept of permitting is well known in the theistic tradition: God does not want $\mathrm{A}$ and does not cause A, although He knows that A will happen because $\mathrm{He}$ knows that $\mathrm{He}$ accepts A's occurrence. If God did not permit A to happen, A could not happen. Can God want events which are unplanned and not caused by Him directly (though permitted)? It seems that Anselm speaks of such events when he contemplates the fall of angels; God did not cause the devil to fall but merely created the possibility of fall, and He knew beforehand that this would happen. In one act of will, God wants and causes directly some events and 
allows other events, which are not directly God-caused, to happen. If we accept that model, simplicity would be consistent with $\left(\mathrm{C}_{1}, \mathrm{C}_{2}, \mathrm{C}_{3}, \mathrm{C}_{4}\right)$.

The next issue is God's risk and lack of control over the world. As has been mentioned before, God, by creating a relatively autonomous world, has not deprived Himself of the possibility of acting therein. At any time, God can cause an event that will change the history of the universe or will affect the entire human species or individuals. Thus, by creating the world with the ability to self-organize and self-create, God did not deprive Himself of the ability to intervene and direct the world, which, in my view, greatly reduces the threat of risk associated with the world's autonomy.

Which meta-philosophical approach is more suitable for theism? Is metaphysics supposed to be prior to science? Or independent of it? It seems that different options are acceptable here. An adherent of the primacy of metaphysics over science can implement their project, and someone who insists on close cooperation between metaphysics and science can proceed with their own project. However, it is worth realizing that both approaches have their weaknesses. Metaphysics (including metaphysics of God) which is detached from the natural sciences can be considered a kind of unlikely speculation. On the other hand, a theist who is ready to circumscribe God's power and His agency according to man-formulated natural laws and the present findings of science (as in epistemic deism) faces the allegation of anthropomorphism and idolatry (see Peter Forrest's paper in this issue).

\section{REPLY TO MARIAN GRABOWSKI}

In the paper "Is Probabilistic Theism a Tenable Idea?" (this issue), Professor Marian Grabowski offers a critical appraisal of the concept of probabilistic theism. He refers to the last chapter of my book (2014), and notes that my view of chance is lacking in recognition of the link between randomness and infinity. Additionally, his objection has it that my presentation of God is one-sided; God is shown mainly as the Savior, and not as God-Creator (including the Creator of "negatives," e.g., chance). He also objects to locating God's actions in the world on the quantum level, as in my book or in Plantinga (2011); this is believed to misrepresent God's transcendence.

Regarding the problem of randomness and infinity: in my book, I adopt the premise that the world has beginning in time, and my consideration is mainly concerned with natural phenomena (e.g., cosmic and biological evolution). Thus, no matter how old and great our universe is, it is finite. 
When it comes to the one-sidedness of my view of God as the Savior only, I do not find this allegation justified because, on innumerable occasions in (2014, 2020), I do recognize God primarily as the almighty Creator of the world. As for the negatives, that is, chance and perhaps evil, Marian Grabowski's conception and my position are different. Let me note here that open theism, Molinism and probabilistic theism hold that God is not the creator of everything. At this point, the concept of creation should be clarified; one can distinguish creation in a strong sense from creation in a weak sense. The former means that God creates $x$ directly; perhaps mathematics could have been created by such an action. Creation in a weak sense means that God directly causes the existence of a certain whole, undetermined in many details, in which $y$ can happen or exist. I claim that God is the creator of everything only in the weak sense. If God were literally the creator of everything, as Grabowski claims, this would be difficult for the problem of human responsibility for evil.

Marian Grabowski considers it to be mistaken to claim that God acts at the quantum level of the world. The thesis I defend is that God can act at all levels of the world, the quantum level included. I am not saying that this is what God does, even less that $\mathrm{He}$ is doing it continuously. On the other hand, I cannot accept the claim that God cannot act in the world as this would violate His transcendence. I believe that God acting in the world does not become one of the things in the world, just as someone who writes on the board does not become part of the board. I understand Marian Grabowski's position in the following way: God does not act in the world because He created the world in full, down to the smallest detail, thereby also covering all negatives.

\section{REPLY TO BŁAŻEJ GĘBURA}

In his paper "On Epistemology of Chance" (this issue), Błażej Gębura refers to my book (2014), and in particular to the appendix dedicated to different types of chance. He concentrates on the epistemology of chance, that is, the possibility of knowing chance; as he argues, certain types of chance, especially what I call "composite chance," are unknowable to us.

I think these epistemological reflections make a valuable complement to the ontological issues included in the book. The ontological consideration is concerned with concepts and relationships between concepts. These concepts make up models of reality and models of relations between entities or events that would fall under these concepts if they existed. From the epistemological point of view, this approach is safe because we can assume that we have good cognitive access to 
the concepts that we ourselves construct; though, on the other hand, it is a minimalist program because in philosophy and science it is more desirable to come to know the world, not merely some hypothetical representations thereof. But it is not excluded that at least certain representations of the world are adequate. The skeptical claim that we cannot discover whether an event is a chance event (provided we assume that such events occur) may also concern events we take as fully determined in each aspect. We may be wrong when we claim that an event has such-and-such cause or purpose; it may well be that Hume was right when he suggested that the causal link between phenomena is simply an illusion. However, the hypothesis of global skepticism is difficult to reconcile with Christian theism. Błażej Gębura does not accept the thesis of global skepticism and defends the possibility of limited knowledge of chance; for example, one can know that an event is the result of intersections of different causal chains.

What is interesting but also debatable in his proposal is the meta-philosophical statement that epistemological inquiries should be independent of scientific knowledge. My belief in the possibility of chance events, especially causeless events, is largely based on the findings of modern science; we are justified in believing that chance is possible because this is what indeterministic interpretations of quantum mechanics say. Gębura considers this approach to be mistaken. However, to my mind, it is difficult to have any knowledge of a genetic mutation of a cell caused by a photon impact without taking into account what modern science says. The question arises what that primacy of epistemology over quantum physics might consist in: Can one demonstrate that scientific knowledge about the microworld is possible and well justified without relying on scientific findings? Or should epistemology focus on demonstrating that scientific knowledge, globally or locally, is impossible and point to inadequate justification for the results of scientific research?

Regarding the possibility of knowing composite chance (i.e., an event that is causeless, unplanned, unpredictable, and pointless), Błażej Gębura holds that it is impossible to know whether a certain event is such an event. I find this view accurate; we cannot know whether a particular quantum event has been caused by God (such causation is possible because God can act at every level of the world), or it is causeless and undetermined in God's plan. This cannot be known because we do not have access to God's will. From the ontological viewpoint, such composite chance events are possible within the framework of probabilistic theism (Łukasiewicz 2014), which assumes the purposeful randomness and possibility of self-determination of the world. From the epistemological perspective, if God exists in time, there may be events unpredictable for Him in the sense that God does not have infallible knowledge that they will happen; and if God is timeless, 
as I think, they are known to God, but they are not predictable for any epistemic agent existing in time.

\section{REPLY TO JACEK WOJTYSIAK}

In "God and Chance," Professor Jacek Wojtysiak (this issue) writes that the existence of the type of chance $\mathrm{C}_{1}$ is treated as a dogma in my paper (this issue). Next, he claims that I define the set of chances $\left(\mathrm{C}_{1}, \mathrm{C}_{2}, \mathrm{C}_{3}, \mathrm{C}_{4}, \mathrm{C}_{5}, \mathrm{C}_{6}\right)$ inconsistently. ${ }^{3} \mathrm{He}$ also argues that, in my version of theism, God has a very limited influence on the world, and thus He is "limited" and helpless in the face of evil.

Is $\mathrm{C}_{1}$ really a dogma in my account? I do not think this allegation is quite accurate. Nowhere in my paper is it claimed that the existence of $\mathrm{C}_{1}$ is a must; but I allow for the possibility that $\mathrm{C}_{1}$ occurs, and analyze how $\mathrm{C}_{1}$ could be compatible with the existence of the almighty God. I assume the existence of the possibility of $\mathrm{C}_{1}$ on the basis of certain modern scientific theories about the quantum world, but I do acknowledge that there are, as noted by Peter Forrest (this issue) and Jeffrey Koperski (this issue), other interpretations of quantum physics (noncollapse models), which do not imply $\mathrm{C}_{1}$. Let us imagine, however, that in the future everyone or almost everyone recognizes, based on available scientific data, that $\mathrm{C}_{1}$ happens in the world. If this were the case, theistic metaphysicists would have three options: reject scientific data, reject theism as unjustified and probably false, or thirdly, change the views concerning causation (the option preferred by Professor Wojtysiak). I aim to show that even if $\mathrm{C}_{1}$ events do occur, theists do not have to abandon their views. I explain the possibility of $\mathrm{C}_{1}$ as resulting from God's idea of creating an autonomous world with the ability to self-determine. Hence, God did not directly cause chance events of $\mathrm{C}_{1}$ type to exist, but He caused that a world in which $\mathrm{C}_{1}$ happens or is possible came into existence. Significantly, this is not a world of complete chaos, but a world in which chance events can be the basis for order at a higher level.

As far as $\mathrm{C}_{2}$ is concerned, inconsistency would emerge if we assumed God's detailed plan for the world, covering every event, including $\mathrm{C}_{1}$ events. However, my position is not that such a plan exists, but rather that there is a general plan, or in other words, a plan defined to some extent only. It is plausible to me that God's creative plan had a form of an indeterminate divine volition, as Peter van Inwagen puts it; God decided that, under $\mathrm{C}_{1}, \mathrm{~A}, \mathrm{~B}, \mathrm{C}$ or D would happen, but $\mathrm{He}$

\footnotetext{
${ }^{3}$ See footnote 1 in the present paper.
} 
did not decide that it is A that would happen and did not cause A directly (van Inwagen 1988).

Chance events $\mathrm{C}_{3}$ cannot be known infallibly if we assume that God exists in time. If God is timeless, $\mathrm{C}_{1}$ can be $\mathrm{C}_{2}$, but it cannot be $\mathrm{C}_{3}$. As regards type $\mathrm{C}_{4}$, it is pointless in the sense that its occurrence does not matter to the whole of which it is a part. For example, if $\mathrm{A}$, which is a $\mathrm{C}_{4}$ event, had not occurred, and instead an event $\mathrm{E}$ had occurred, that would not be relevant to a certain whole within which this happened. Type $\mathrm{C}_{1}$ can be $\mathrm{C}_{2}$ and $\mathrm{C}_{4}$. $\mathrm{C}_{1}$ can also be $\mathrm{C}_{5}$, but it cannot be $\mathrm{C}_{6}$.

By permitting $\mathrm{C}_{4}$, God may have a purpose; this could be a greater variety of events in the world, or it could be another goal, like independence of the universe. But this does not change the fact that a token of $\mathrm{C}_{4}$ itself is pointless and unplanned; $\mathrm{C}_{4}$ can also be $\mathrm{C}_{1}$.

The supposed inconsistency would result if the set of chances $\left(\mathrm{C}_{1}, \mathrm{C}_{2}, \mathrm{C}_{3}, \mathrm{C}_{4}\right.$, $\mathrm{C}_{5}, \mathrm{C}_{6}$ ) was defined as a conjunction, but it is defined as an alternative. Besides, I do not claim that all combinations (64) are compatible with each other. The point is that only certain combinations are possible and they can be considered as combinations of types of chance. Thus, so long as Professor Wojtysiak, when noting inconsistencies, means that there are some incompatible combinations of chance types in the set $\left(\mathrm{C}_{1}, \mathrm{C}_{2}, \mathrm{C}_{3}, \mathrm{C}_{4}, \mathrm{C}_{5}, \mathrm{C}_{6}\right)$, he is right; but it is wrong to claim that all combinations are incompatible.

Finally, I want to address the objection that God has limited control over the world. In the open probabilistic theism (see my paper in this issue), nothing limits the possibilities of God's action: neither the nature of the created world nor the laws of nature. I am not saying anywhere that God has created a world in which He does nothing; on the contrary, the world is causally open to God's actions and is constantly maintained in existence. Regarding God's alleged powerlessness against evil, there are, in general, two possibilities. First, God created the world, including free persons capable of self-determination, without planning every event (and every evil) in detail (to know that something will happen does not mean to want it to happen). Second, everything has been carefully planned down to the smallest detail, and it can be said that this world is the best of possible worlds. I find the first possibility more convincing and morally more acceptable; the second appears to be advocated by Jacek Wojtysiak (this issue) and the adherents of the idea of concurrentism. 


\section{REFERENCES}

BertalanfFy, Ludwig von. 1968. General System Theory. New York: George Braziller.

BertalanfFy, Ludwig von. 1975. Perspectives on General Systems Theory: Scientific-Philosophical

Studies. Edited by Edgar Taschdjian. New York: George Braziller.

CraIG, William Lane. 1987. The Only Wise God. Grand Rapids: Baker Book House.

Flint, Thomas P. 2020. "Providence, Chance, Divine Causation, and Molinism: A Reply to

Łukasiewicz." Roczniki Filozoficzne 68 (3): 55-69.

Forrest, Peter. 2020. "Chance or Agency? A Response to 'Divine Providence and Chance in the World'." Roczniki Filozoficzne 68 (3): 111-25.

GĘBURA, Błażej. 2020. “On Epistemology of Chance.” Roczniki Filozoficzne 68 (3): 221-32.

Grabowski, M. 2020. "Is Probabilistic Theism a Tenable Idea? Critical Remarks on Opatrzność Boża, wolność, przypadek." Roczniki Filozoficzne 68 (3): 205-20.

Guillon, Jean-Baptiste. 2020. "Divine Providence: Fine-Grained, Coarse-Grained, or Something in Between?" Roczniki Filozoficzne 68 (3): 71-109.

HASKER, William. 1989. God, Time, and Knowledge. Ithaca, NY-London: Cornell University Press.

HASKER, William. 2000. "A Refutation of Middle Knowledge." In Middle Knowledge Theory and Applications, edited by William Hasker, David Basinger, and Eef Dekker, 66-77. Frankfurt am Main-New York: Peter Lang.

HASKER, William. 2008. The Triumph of God over Evil. Theodicy for a World of Suffering. Downers Grove, IL: Inter Varsity Press.

HASKer, William. 2020. "How to Make a World.” Roczniki Filozoficzne 68 (3): 35-54.

Heller, Michał. 2014. Sens życia i sens wszechświata. Kraków: Copernicus Center Press.

JUDYCKI, Stanisław. 2020. "God's Insurmountable Will and the Mystery of the Freedom of Created Beings: Comments on the book Opatrzność Boża, wolność, przypadek by Dariusz Łukasiewicz." Roczniki Filozoficzne 68 (3): 137-47.

KLESZCZ, Ryszard. 2020. "Chance and Divine Providence: Methodological Notes with Pascal in the Background." Roczniki Filozoficzne 68 (3): 169-85.

KOPERSKI, Jeffrey. 2020. "Divine Action and the Laws of Nature: A Reply to Łukasiewicz." Roczniki Filozoficzne 68 (3): 127-36.

LASZlo, Ervin. 1972a. Introduction to Systems Philosophy. New York: Gordon and Breach.

LaSZLO, Ervin. 1972b. The Systems View of the World: The Natural Philosophy of the New Developments in the Sciences. New York: George Braziller.

ŁUKASIEWICZ, Dariusz. 2014. Opatrzność Boża, wolność, przypadek. Studium z analitycznej filozofii religii. Poznań: W drodze.

ŁUKASIEWICZ, Dariusz. 2020. "Divine Providence and Chance in the World." Roczniki Filozoficzne 68 (3): 5-34.

ŁUKASIEWICZ, Elżbieta. 2006. "What Kind of System is Language? On the Relevance of General Systems Theory to Language Studies." Scripta Neophilologica Posnaniensia 8: 97-113.

ŁUKASIEWICZ, Elżbieta. 2008. "Czy język to projekt doskonały? Zasada ekonomii w strukturze języka i założeniach programu minimalistycznego." Filozofia Nauki 16 (1): 27-40.

MordARSKI, Ryszard. 2020. "Probabilistic Theism and the Classical Doctrine of Actus Purus. Roczniki Filozoficzne 68 (3): 187-203.

Plantinga, Alvin. 2011. Where the Conflict Really Lies: Science, Religion and Naturalism. Oxford: Oxford University Press.

Rogers, Katherin A. 2008. Anselm on Freedom. Oxford: Oxford University Press.

SwInbURne, Richard. 1993. The Coherence of Theism. Oxford: Oxford University Press.

WoJTYSiAK, Jacek. 2020. "God and Chance." Roczniki Filozoficzne 68 (3): 233-47. 
VALliCElla, William F. 2010. "Divine Simplicity." The Stanford Encyclopedia of Philosophy (Fall 2010), edited by Edward N. Zalta. http://plato.stanford.edu/archives/fall2010/entries/divinesimplicity.

Van Inwagen, Peter. 1988. "The Place of Chance in a World Sustained by God." In Divine and Human Action: Essays in the Metaphysics of Theism, edited by Thomas V. Morris, 211-35. Ithaca, NY: Cornell University Press.

ZIEMIŃSKI, Ireneusz. 2011. "Argumenty za istnieniem Boga.” In Przewodnik po metafizyce, edited by Sebastian T. Kołodziejczyk, 549-92. Kraków: Wydawnictwo WAM.

ZIEMIŃSKI, Ireneusz. 2020. "Is God (Perfectly) Good? Remarks on Opatrzność Boża, wolność, przypadek by Dariusz Łukasiewicz. Roczniki Filozoficzne 68 (3): 147-67.

\section{DIVINE PROVIDENCE AND CHANCE IN THE WORLD: REPLIES}

\section{S u m m ary}

In the paper, I reply to the objections contained in the other papers in this issue raised against my conception of providence and chance presented in the opening article and the book from 2014 I argue that the existence of variously understood random events (chance) does not imply the thesis that God, the Creator of the world is not interested in the fate of individual creatures, including human beings. The reason why God can permit random events to occur is God's will to create a relatively autonomous world that has the ability to self-develop and self-create. In such a world, there may be pointless evil for which God is not directly responsible.

Keywords: God; chance; free will; providence; evil.

\section{OPATRZNOŚĆ BOŻA A PRZYPADEK W ŚWIECIE: ODPOWIEDZI}

\section{Streszczenie}

W artykule przedstawiam odpowiedzi do zarzutów, zawartych w innych artykułach tego numeru, wobec proponowanej przeze mnie w artykule otwierającym oraz monografii z roku 2014 koncepcji opatrzności i przypadku. Argumentuję, że istnienie różnie rozumianych zdarzeń przypadkowych nie implikuje tezy, że Bóg Stwórca świata nie interesuje się losem indywidualnych bytów stworzonych, w tym istot ludzkich. Staram się w swoich odpowiedziach pokazać, że powodem, dla którego Bóg może dopuszczać występowanie zdarzeń przypadkowych jest Boża wola stworzenia świata względnie autonomicznego, który ma zdolność samodzielnego rozwoju. W świecie takim może występować zło bezcelowe, za które Bóg nie ponosi bezpośredniej odpowiedzialności.

Słowa kluczowe: Bóg; przypadek; wolna wola; opatrzność; zło. 